\title{
VERIFICATION OF THE DELETERIOUS EFFECTS OF LERNAEOSIS ON THE HEALTH OF GRASS CARP (CTENOPHARYNGODON IDELLA)
}

\author{
Manal A. A. Essa', Mohamed A. A. Abd El-Galil', Wahid M. A. \\ Mousa $^{2}$ and Showky. S. Ibrahim ${ }^{3}$ \\ 1 Fish Dept. Fac. Vet. Med. Beni-Suef, Cairo Univ. \\ 2 Parasitology Dept., Fac. Vet. Med.. Cairo Univ. \\ 3 Physiology' Dept., Fac. Vet. Med. Beni-Suef. Cairo Univ.
}

keywords : parasites. Lernaea cyprinacae, mortality, hematallogy. histopathology, biological stress, cortisol.

Crenopharyngodon idella. experimental infestation.

\begin{abstract}
Gxperimental infestation of Ctenopharyngodon idella $(80-90 \mathrm{~g})$ Cwith laboratory reared first copepodid stage of Eernaea cyprinacea (a parastitic copepod) resulted in clinical lernaeossis. The mortality rate reached up to $40 \%$ of the infested group within a month at $26 \pm 2^{\circ} \mathrm{C}$. The sequential clinical abnormalities. histolopathological and hematological alterations with elevation in the cortisol levvel had verified experimentally the deleterious effects of lernizeosis on the health of $C$. idclla. Periodical examination of the experimentally infested $C$. idella cleared that the females parasites were the most physically detrimental stage to the fistz with regard to their mode of attachment and cortisol response. Induction of lernaeosis in the present investigation may be important when attempting to develop useful effective protective and / or curative measures for lernaeosis in C. idella and probably in other cyprinids.
\end{abstract}

\section{INTRODUCTION}

Nowadays, the grass carp (Ctenopharyngodon idella) igains a special attention in Egypt, for its role in weed control in the River Nile and its tributaries (Bishai and Khalil, 1997). During rearing of such fish in the hatchery, a copepod parasite belonging to genus Lernaea poses a major constraint to its different age groups. Most Egyptian investigations concerning lernaeosis (Faisal et $\mathrm{cl}$., $2988 ; \mathrm{El}$ Bouhy et al., 1989; Aly et al., 1995; Essa et al., 1995; Mahfouz, 
1997; Abd El Galil, 1998; El Nobi, 1998; El Seify el al., 1998; Abd El Rahman, 2000; Adawy, 2000 \& Hanna, 2001) were limited in their scope to those which could be conducted using naturally infested fish. For better understanding of the disease process and fish protection from lernaeosis outbreaks, successful laboratory maintenance of this parasite is urgently needed. Fortunately, the procedures for laboratory rearing of the most ubiquitous species, Lernaea cyprinacea, were fully described by Shields (1978). However, the biology, taxonomy, systematics, distribution and pathology of Lernaea have been studied extensively (e.g., Shields and Tidd, 1968, 1974; Kabata, 1970, 1979; Shields and Sperber, 1974), but there have been few reports on its pathogenic effects and host response to the parasite. It is noteworthy that also in Egypt, no study was so far carried out for clarification of these intriguing areas to date. Therefore, this work was planned to fill such gap. Infestive first copepodid stage was reared in the laboratory. for experimental induction of lernaeosis. Consequently, deleterious effects of lernaeosis, namely mortalities, clinical abnormalities, postmortem lesions, hematological changes, serum cortisol and histopathological alterations were assessed in experimentally infested C. idella.

Fish:

\section{MATERIAL AND METHODS}

A total of one hundred apparently healthy $C$. idella with an almost equal body weight ranging from $80-90 \mathrm{~g}$ were collected alive from Naga-Hamady hatchery. They were equally divided in two 800 L fiberglass tanks which were supplied by chlorine free tap water and air supply. Water temperature was adjusted at $26 \pm 2^{\circ} \mathrm{C}$. The experimental fish were kept under observation for a month to be sure that they were free from Lernaea infestation (Woo and Shariff, 1990). During this period, fish were fed twice daily at a rate of $3 \%$ of body weight with commercial pelleted food.

The parasite:

Adult female Lemaea parasites were collected from naturally infested $C$. idella by means of fine forceps and scissors according to Hoffmann (1970).

In vitro, rearing of the $1^{\text {st }}$ copepodid stage :

Egg sacs were removed from adult females, then placed in a covered petri dish containing chlorine free tap water and incubated at $29^{\circ} \mathrm{C}$ as described by Shields (1978). After 24 hours, all unhatched eggs and remnants of hatched egg sacs were removed. Throughout 


\section{DELETERIOUS EFFECTS OF LERNAEOSIS ON GRASS CARP (CTENOPHARYNGODON IDELLA)}

80-85 hr post hatching, the infestive $1^{\text {st }}$ copepodid stage was developed.

\section{Experimental infestation:}

Fifty apparently healthy $C:$ idella were exposed to laboratory reared $1^{\text {st }}$ copepodid of $L$. cyprinacea. Fish were immersed in water containing the infestive stage (40-50 larvae / fish) for approximately 5 minutes (Shields, 1978). The remaining post exposure water was then emptied into the holding tank. The remaining fifty experimental tish in the other tank were left without infestation as control.

Experimental design:

For four weeks post experimental infestation, the sequential lernaeal infestation effects were estimated. Mortalities, clinical abnormalities, post-mortem lesions were recorded throughout the observation period. Five infested fish and other five control ones were sacrificed each week for following up the hematological changes, cortisol level and histopathological alterations.

Clinical examinations:

All investigated fish were individually inspected as described by Post (1987) and Stoskopf (1993) for detection of any gross lesions and / or visible parasitic copepod.

Hematological examination:

Heparainized blood samples were collected according to Lucky (1977) for determination of RBCs and total WBCs counts (Kanaev, 1985), HB concentration, PCV value and differential leucocytic count (Jain, 1986).

\section{Hormonal assay:}

After serum separation from heparinized blood samples as noted by Poole et al (2000), the serum cortisol level was quantified by competitive immunoassay according to Balm et al. (1994). Histopathological examination:

The skin and underlying muscles of the experimentally infested and control uninfested fish were fixed in 10\% formalin, embedded in paraffin and stained with Hematoxylin \& Eosin (H \& E) according to the method described by Hibiya (1982).

Statistical analysis:

The data collected were statistically analyzed for mean, standard error and significance of the results according to Snedecor and Cochran (1976). 


\section{RESULTS}

\section{Mortalities:}

The mortality percentages among experimentally infested and control fish are shown in Table (1).

2. Clinical abnormalities and post-mortem lesions:

During $1^{\text {st }}$ week, behavior changes were detected in the form of rapid swimming with short resting periods and respiratory distress. On the $10^{\mathrm{it}}$ day, petechial haemorrhages were noticed at the base of the dorsal fin. On the $14^{\text {th }}$ day, the body of the embedded parasite could be seen (Photo, 2). At the $3^{\text {rd }}$ week, erythemic foci surrounded the adult females present at the bases of the caudal, pectoral and pelvic fins. Also. some fish showed naris attached parasites (Photo 3). During $4^{\text {th }}$ week, the macroscopic inflammation with the adult females spread on the body surface of the infested fish. Dissection of dead and sacrificed samples revealed embedding of the cephalic region of the parasite with part of its body in the skin and underlying musculature. At the end of the observation period, some examined fish had parasitic copepods attached to the gills, inner surface of the operculum and oral cavity (Photos 4 \& 5). Infestation percentages and means of infestation intensity are shown in Table (2) and Figure (1). Neither clinical abnormalities nor post-mortem lesions were seen among control fish.

\section{Hematological changes:}

The results in Table (3) and Figures (2-4) showed reduction in erythrocytic count, hemoglobin concentration and packed cell volume in experimentally infested $C$. idella. These changes became significant from the second week in case of erythrocytic count and from the third week in olher parameters.

Also the results in Table (4) and Figures (5-9) cleared a significant increase in the total leucocytic count in the third and fourth weeks post infestation. The lymphocytes percentage was significantly decreased, while the heterophils and eosinophils percentages were significantly increased. These changes appeared from the second week. The increase in the monocytes percentage began to be significant two weeks post-infestation. 
4. Serum cortisol level variations:

The cortisol levels were determined in experimentally infested $C$. idella with $L$. cyprinacea and control fish at weekly intervals. The results in Table (5) and Figure (10) showed a significant increase in the cortisol level in experimentally infested fish from first week post infestation till the end of the observation period.

5. Histopathological alterations:

I-Seven days post experimental infestation:

The skeletal muscle underlying the dermal layer was infiltrated by mononuclear leucocytic inflammatory cells in focal manner with appearance of part of the infesting parasile in the subcutaneous tissue (Photo 6)

II-Fourteen days post experimental infestation:

Massive number of leucocytic inflammatory cells were infiltrated the degenerated epidermal layer, while the dermal layer showed a wide area of aggregated granular acidophilic cells (Photo 7). The subcutaneous tissue was edematous and intiltrated by mononuclear leucocytic inflammatory cells. There was a diffuse line of pigments between the necrosed muscular layer and subcutaneous tissue (Photo 8). Myxomatous degeneration was noticed in focal manner at the subcutaneous connective tissue. Part of parasite was noticed embedded in the epidermal layer.

IIl- Twenty-one days post experimental infestation:

Edema with inflammatory cells infiltration were noticed in the subcutaneous tissue (Photo 9), with focal infiltration of inflammatory cells in the underlying muscle.

V- Twenty - eight days post experimental infestation:

The epidermal layer was degenerated and infiltrated by inflammatory cells while the subcutaneous tissue and the underlying muscle showed focal leucocytic inflammatory cells infiltration. Part of the parasite was embedded in the musculature (Photo 10).

\section{DISCUSSION}

Lernaea parasite is a most commonly known injurious parasite of warm freshwater fish in different parts of the world. In Egypt, the importation of genetically selected stocks of cyprinids was associated with the inadvertent introduction of lernaeosis that settle under Egyptian environment. Since eighteens, spreading of lernaeosis 
among cultured fish in local farms and hatcheries causes annual economic losses as a consequences of fish mortalities and costs of ineffective control measures. Immunologic control methods are recent approach for controlling various parasitic infestations in fish. However, studies on this strategy are hampered in Egypt due to lack of research concerning laboratory rearing of Lernaea parasite. Therefore, in the present study, experimental induction of lernaeosis was carried out and responses in the experimentally infested $C$. idella were described for the first time. All changes were followed up for four weeks post copepodid's exposure, because fish usually lost their infection 30 days after challenge with $L$. cyprinacea (Woo and Shariff, 1990).

$40 \%$ mortalities were detected during 4 weeks post experimental infestation (Table 1). Various losses were also reported by Sarig (1971), Faisal et al. (1988), Gun'hovskii and Khudalei (1989) and Abd El Rahman (2000) in naturally infested fish. Aly ef al... (1995) attributed these deaths of infested fish to impairment of some skin functions as osmoregulations and excretion.

Concerning the detected clinical abnormalities and postmortem lesions in experimentally infested $C$. idella, the behavior changes were in the form of rapid swimming and fish rubbing against the tank walls mostly due to irritation caused by the attached parasites as a trial to get rid of the parasite (Woo and Shariff, 1990). Also, surfacing, air gasping and increased opercular movements suggested the gill infestation with Lernaea. On the fourteenth day, the embedded females could be seen by naked eye. Shariff and Roberts (1989) reported similar results in the experimentally infested Aristichthys nobilis by Lernaea polymorpha. Macroscopic inflammation around adult female and distribution pattern of the skin lesions (Photos 2-5), were nearly similar to copepod infested lesions in the naturally infested cyprinids (Abd El Rahman, 2000; Abd El Galil, 2002). Moreover, the parasitic females attached to the gills, inner surface of the operculum. isthmus, lower jaw and nares detected only in the experimentally infested fish. Several authors also noted the attachment of L. cyprinacea to such sites as Post (1987); Carlos (1997) and Abd El Rahman (2000). As seen in naturally infested cyprinids in the previous investigations (Abd El Rahman, 2000 and Abd El Galil, 2002), adult females did not exceed the skin and underlying muscles. Shariff and Roberts (1989) described similar changes in naïve Aristichthys nobilis experimentally infested with $L$. polymorpha. The clinical infestation percentage reached $100 \%$ and 
mean of infestation intensity was 9.4 at the end of the observation period (Table 2 and Fig. 1). These data may support the suggestion that $C$. idella used for experimental work can be considered unimmune, where the clinically immune fish rejects the parasite on exposure to infestation.

On hematological examination of the experimentally infested C. idella, reduction of RBCs count, hemoglobin concentration and packed cell volume were detected one week post infestation (Table 3 and Figs. 2-4). The decrease in these blood parameters was increased gradually by time to be significant in the second week in case of erythrocytic count, and from the third week in the remaining ones. The increase in tota! leucocytic count was significant at three weeks post infestation. On the other hand, heterophils and eosinophils counts elevation and lymphocytes count reduction became significant in the second week. while significant increase in monocytes occurred in the second week (Table 4 and Figs. 5-9). Nearly similar hematological changes were noticed also in naturally infested (. idella (Abd El Galil, 2002). Kabata (1970) and Abd El Rahman (2000) mentioned that the counter productive effect of lemacosis on hematologic indices seems to be related to parasite feeding behavior and/or inflammatory reaction that counter $L$. cyprinacea infestation.

In addition, estimation of cortisol level in experimentally infested $C$. idella every week throughout the post infestation period showed a significant increase in the cortisol level in infested fisin than control ones from the first week post infestation till the end of the experiment (Table 5 and Fig. 10). Also. Abd El Galil (2002) reported the elevation of cortisol level in naturally infested $($ : idella. Similar stress response in Allanic salmon exposed to a single experimental challenge with sea lice was noticed by Bowers el al.... (2000). The elevation in cortisol levels goes parrellel with the disease progression. indicating that lemaeosis is stressful (Mesa et al... 2000). Nlthough. the relationship between hematological changes and cortisol response in lemaeosis affected fish has not received a great deal of attention. the present results suggest possible causal links between cortisol elevation and hematological changes. Alternatively. these blood changes may be caused by a combination of direct effect of the parasite and stress mediated mechanism induced by lernaeosis.

The periodical histopathological examination of the skin of the experimentally infested $C$. idella describes the histopathological changes, which accompany the copepodid invasion and development 
to adult female. Penetration of the parasite into the host subcutaneous tissue was apparent seven days post experimental infestation (Photo 6). Shariff and Roberts (1989) reported also penetration of Lernaea polymorpha into the naïve Aristichthys nobilis tissue at 13 days after the fish were exposed to the newly hatched larvae. This difference in the duration may be due to variation in the infective material. The newly hatched larvae of Lernaea polymorpha needs around $312 \mathrm{hrs}$ to develop to $1^{\text {st }}$ copepodid (Shariff and Roberts 1989), while the development of the infestive first copepodid of $L$. cyprinacea in this study occurred at 72-80 hours post hatching. Also. after seven days. the leucocytic inflammatory. cells infiltrated within the muscle underlying the dermal layer as early inflammatory response. At 14 days after infestation, the mononuclear cells became abundant and extended to infiltrate the edematous subcutaneous tissue and the degenerated epidermal layer (Photo 7). Joy and Jones (1973) and Shariff and Roberts (1989) had documented the presence of inflammatory response to Lernaea. In addition to mononuclear cells, eosinophilic granular cells were noticed for the first time in the dermal layer. Shariff and Roberts (1989) noted similar findings at 10 days after $L$. polymorpha infestation of naive fish. On the other hand, the appearance of a diffuse line of pigments between the necrosed muscular layer and subcutaneous tissue was also recorded by Shariff and Roberts (1989) but on the fifth day after Lernaea penetration. The specimens examined at 21 and 28 days did not differ markedly from the previous ones but the parasite migrate to be embedded in the musculature (Photo, 10). Most detected changes nearly resemble these in naturally infested $C$. ide/la (Abd El Galil, 2002).

In conclusion. the infestation of L.cyprinacea causes detrimental effects in C. idella. with greatest effects during stages of its life cycle when parasitic females are embedded in the host tissues. Apart from direct consequences of Lernaea infestation, host damage may arise indirectly as a result of opportunistic infections and increased stress response (Wooten et al.,., 1982). Because this investigation was conducted in a laboratory situation thus limiting the opportunity for infection by other pathogens, the possibility of causative effects of stress response is more accepted.Thus, more studies are needed to draw a definite conclusion.

To sum up, it is hoped that the success in induction of lernaeosis in $C$. idella will hasten the development of effective safe means for prevention and/or controlling lernaeosis in Egypt. 


\section{REFERENCES}

Abd El Galil. M. M. A. (1998). Studies on some fish pathogens affecting freshwater fishes in Beni-Suet hatchery. Thesis of M.V.Sc.. Fish Diseases and Management. Fish Dept., Fac. Vet. Med.. Beni-Suif, Cairo Univ.

Abd El Galil. M. M. A. (2002). Studies on lemaeosis in cultured freshwater fish in Beni-Suef governorate. Ph.D thesis. Fish diseases and Management. Fish Dept.. Fac. Vet. Med., BeniSuef. Cairo Univ.

Abd El-Rahman. M. M. (2000). Studies on cultured fish diseases induced by Lernaea spp. Thesis, of Ph. D. "Fish Disease and Management. Fac. Vet. Med.. Suez Canal Univ.

Adawy, S. M. (2000). Studies on parasitic diseases of some freshwater fishes in Dakahlia Governorate. Ph. D. Thesis, Fish Dis. \& Manage., Vet. Med. Sc., Cairo Univ.

Aly. S. ; Mayberry, L. ; El-Melegy, A. and El-Gawady H. (1995). Pathological studies on parasitic infections in common carp. Egypt. J. Comp. Pathol. and clin. Pathol., 8(2): 123-130.

Balm. P. H. M. P. ; Pepels, S. ; Helfrich M. L. M. ; Hovens and Wendelaar Bonga, S. E. (1994). Adrenocorticotrophic hormone in relation to interrenal function during stress in tilapia (Oreochromis mossambicus). General Comparative Endocrinology, 96:347-360.

Bishai, H. M. and Khalil, M. T. (1997). Freshwater fishes of Egypt. Publ. National Biodiversity Unit, 9: 192pp.

Bowers, J. M. ; Mustafa, A. ; Speare, D. J. ; Conboy, G. A. : Brimacombe, M. ; Sims, D. E. and Burka, J. F. (2000). The physiological response of Atlantic Salmon, salmo Salar L., to a single experimental challenge with sea lice, Lepeophtheirus slamonis. J. Fish Dis., 20:165-172. 
Carlos, S. M. E. A. S. (1997). Ectoparasites of some fishes in Laguna de Bay (Philippines). College, Laguna, (Philippines), June 54 Leaves.

El Bouhy, Z. M. ; Saleh, G. and Ali, A. A. (1989). Studies on Lernaea infestation in some commercial fishes at Sharkia province. Vet. Med. J. Giza, 37(3): 345-365.

El Nobi, G. A. A. (1998). Parasitic diseases affecting cultured fish and its influences by some ecological factors. Ph. D. Thesis, Fish Diseases and Management., Vet. Med. Sc. Zagazig Univ.

El Seify, M. A. ; Soliman, M. K. and Mahfoz, N. B. (1998). Effect of Parasitism on certain inmunological parameters of cultured fishes". Egypt. J. Aquat. Biol. and Fish., 2(4) : 79-405.

Essa, A. A. Manal ; Mahdy, O. A. and Essa, M. El-S. (1995). lernaeosis outbreak in cultured freshwater fish fingerlings at Kafr El-Sheikh Governorate, Egypt. Egypt. J. Comp. Pahtol. And Clin. Pathol., 8(2) : 109-121.

Fasial., M. ; Essa, M. El-S. ; Shalaby, S. I. and Ibrahim. M. M. (1988). Epizootic of Lernaea cyprinacea (Copepod lernaeidae in cyprinid) imported to Egypt. Egypt J. Comp. Pathol. And Clin Pathol.. 1: 127-148.

Gun'hovskii, S. A. and Hkudalei, G. A. (1989). Lernaeosis in farmed Salmonids. Vestink-Zoologi, I: 65-67.

Hanna, M. I. (2001). Epizootiological studies on parasitic infections in fishes cultured under different fish culture system in Egypt. Thesis of M. V. Sc., Fac. Vet. Med., Cairo Univ.

Hibiya. T. (1982). An Atlas of Fish Histology. Kodansha Lid. Tokyo. Hoffman, G. L. (1970). Parasites of North American freshwater fishes. Univ. California Press, Barkdey and Los Angeles, $2 \mathrm{lpp}$.

Jain, N. C. (1986). "Schalm's Veterinary Hematology". $4^{\text {th }}$ Edition, Lea and Febiger. Philadelphia, USA. pp 35-44. 
Joy, J. E. and Jones. L. B. (1973). Observations on the inflammatory response within the dermis of white bass, Morone chrysope (Rafinesque), infected with Lernaea cruciata (Copepoda: Caligidea). .. Fish Biol., 5:21-23.

Kabata, Z. (1970). Diseases of Fishes. Book I: Crustacea as enemies of Fishes. T.F.H. Publications, Jersey city, N. J.

Kabata, Z. (1979). Parasitic copepoda of British Fishes. Royal society. London.

Kanaev, A. E. (1985). Fish Pathology. British Crown Colony of Hong Kong. 154pp.

Lucky, Z. (1977). Methods for the diagnosis of fish diseases. American publishing Co., PV. Ltd., Newdelhi Bombay Calcutta and New York.

Mahfouz, P. Nadia (1997). Effect of parasitism on immunity in cultured freshwater fish. Ph. D. Thesis, Vet Med. Sc., Kafr El Shekh, Tanta Univ.

Mesa, M. G. : Maule. A. G. and Schreck. C. B. (2000). Interaction of infection with Renibacterium salmoninarum and physical stress in juvenile Chinook salmon. Physiological responses, disease progression and mortality. Trans. Am. Fish Soc.. 129.. 1, 158-173.

Poole, W. R. : Nolan. D. \& Tully, O. (2000). Modeling the effect of capture and sea lice (Lepeophtherius salmonis (kroyer)) infestation on the cortisol stress response in trout. Aquacult. Res., 31:835-841.

Post, G. (1987). Text Book of Fish Health T.F.H. Publications Inc. 151-153.

Sarig; S. (1971). The prevention and treatment of diseases of warmwater fish under sublropical conditions, with especial emphasis on intensive fish farming. In diseases of fishes edit by S. F. Snieszko and H. R. Axelord. Book, 3:67-96. 
Shariff, M. and Roberts, R. J. (1989). The experimental histopathology of Lernaea polymorpha Yu, 1938 infection in naïve Aristichthys nobilis (Richardson) and a comparison with the lesion in naturally infected clinically resistant fish. $\mathrm{J}$. Fish Dis., 12: 405-414.

Shields, R. J. (1978). Procedures for laboratory rearing of Lernate cyprinacea (Copepoda). Grustaceana, 35(3): 259-264.

Shields, R. J. and Sperber, R. G. (1974). Osmotic relationships of Lernaea cyprinacea L. (Copepod). Crustaceana. 26:157-171.

Shields. R. J. and Tiddl. W. M. (1968). Effect of temperature on the development of larval and transformed females of Lernciect cyprincteca L. (Lernaeiidae). Crustaceana. Suppl. 1. Studies on the copepoda. 87-95.

Shields, R. J. and Tidd, W. M. (1974). Site selection on hosts by copepodids of Lernaea cyprinacea L: (Copepoda). Crustaceana, 27:225-230.

Snedecor, G. W. and Cochran W. G. (1976). Statistical Methods. $6^{1 / 2}$ Edition Ames Iowa State Press U.S.A.

Stoskopf, M. K. (1993). Fish Medicine. W. B. Sounder company, Philadelphia, 113-131.

Woo, P. T. K. and Shariff, M. (1990). Lernaea cyprinacea L. (Copepoda: Caligidae) in Helostoma temminicki. Cuvier and valenciennes: The dynamics of resistance in recovered and naïve fish. J. Fish Dis., 13: 485-494.

Wootten R. ; Smith, J. W. and Needham, E. A. (1982). Aspects of the biology of the parasitic copepods Lepeophtherius slcmonis and Caligus elongates on farmed salmonids, and their treatment. Proc. R. soc. Edinb., 81 B, 185-197. 
Table (1): Mortality percentages in experimentally infested glass carp

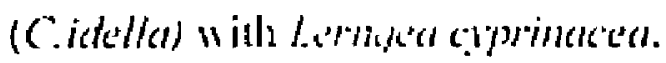

\begin{tabular}{|c|c|c|c|}
\hline $\begin{array}{c}\text { Time } \\
\text { (weeks) }\end{array}$ & $\begin{array}{c}\text { Number of } \\
\text { experimentally infestedl } \\
\text { fish }\end{array}$ & $\begin{array}{c}\text { Cumulative } \\
\text { number of dead } \\
\text { fisl }\end{array}$ & $\begin{array}{c}\text { Cumulative } \\
\text { mortality } \\
\%\end{array}$ \\
\hline 0 & 50 & 0 & 0 \\
\hline 1 & $40^{*}$ & 6 & 12 \\
\hline 2 & $39^{*}$ & 6 & 12 \\
\hline 3 & $30^{*}$ & 10 & 20 \\
\hline 4 & $15^{*}$ & 20 & 40 \\
\hline Control & 50 & 0 & 0 \\
\hline
\end{tabular}

* At the end of eateh weck. 5 lish werte sicrificed

Table (2): Percentages of clinical inlestation and meins of infestation intensily

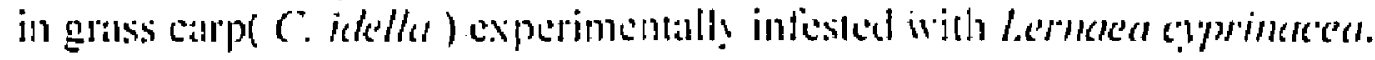

\begin{tabular}{|c|c|c|c|c|c}
\hline $\begin{array}{c}\text { Time } \\
\text { (weeks) }\end{array}$ & $\begin{array}{c}\text { Number of } \\
\text { examined } \\
\text { Fish }\end{array}$ & $\begin{array}{c}\text { Number of } \\
\text { clinically } \\
\text { infested fislı }\end{array}$ & $\begin{array}{c}\text { Clinical } \\
\text { infestation }\end{array}$ & $\begin{array}{c}\text { Infest. } \\
\text { Intensity } \\
\text { range }\end{array}$ & $\begin{array}{c}\text { Infest. } \\
\text { Intensity } \\
\text { means }\end{array}$ \\
\hline 0 & 50 & 0 & 0 & 0 & 0 \\
\hline 1 & $44^{*}$ & 0 & 0 & 0 & 0 \\
\hline 2 & $39^{*}$ & 13 & 3.3 .3 & $1-7$ & 3.2 \\
\hline 3 & $30^{*}$ & 18 & 60 & $3-24$ & 10.8 \\
\hline 4 & $15^{*}$ & 15 & 100 & $2-29$ & 9.4 \\
\hline
\end{tabular}

* At the end of each weck. 5 fish were sacriliced 
Table (3): Mean values $\pm \mathrm{SE}$ of hematological paraneters in grass carp( $C$. ide/lo) experinenlally infested with Lernarea coprinacea

\begin{tabular}{|c|c|c|c|c|}
\hline $\begin{array}{c}\text { Timc" } \\
\text { (weeks) }\end{array}$ & Fish group & $\underset{\mathrm{mm}^{3}}{\mathrm{RBCs} \times 10^{4} /}$ & $\begin{array}{l}\mathrm{Hb} \\
\mathrm{g} / \mathrm{dI}\end{array}$ & $\begin{array}{l}P C V^{\prime} \\
\%\end{array}$ \\
\hline \multirow{2}{*}{1} & Infested & $1.67 \pm 0.02$ & $5.85 \pm 0.23$ & $26.9=0.82$ \\
\hline & Control & $1.73 \pm 0.03$ & $6.23 \pm 0.24$ & $29=1.2$ \\
\hline \multirow{2}{*}{2} & Infested & $1.59 * \pm 0.03$ & $5.52 \pm 01.3$ & $24.8=0.6$ \\
\hline & Control & $1.70 \pm 0.03$ & $6.15 \pm 0.3$ & $26.6 \pm 0.9$ \\
\hline \multirow{2}{*}{3} & Infested & $1.53^{*}=0.03$ & $4.74^{*} \pm 0.25$ & $23.8^{*}=0.6$ \\
\hline & Control & $1.66 \pm 0.04$ & $5.79 \pm 0.3$ & $20.8=0.1 .2$ \\
\hline \multirow[b]{2}{*}{4} & Infested & $1.48 * \pm 0.01$ & $4.51^{* *} \pm 0.25$ & $\begin{aligned} 23.4 & \\
& 0.6\end{aligned}$ \\
\hline & Control & $1.69 \pm[.115$ & $0 \pm 0.2 .3$ & $27.4 \pm 0 . .52$ \\
\hline
\end{tabular}

"Signilicanu diflerence from control group all $p<0.05$

* th 1 lighly signilicals dilierence fiom control group at p<(1.001

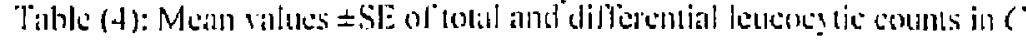

idelia (glass calp) experimentally inlested with /. cyprinteres

\begin{tabular}{|c|c|c|c|c|c|c|}
\hline \multirow[t]{3}{*}{$\begin{array}{c}\text { Time } \\
\text { (wectis) }\end{array}$} & $\begin{array}{l}\text { Fish } \\
\text { group }\end{array}$ & $\begin{array}{c}\text { WBCs } \\
X 10 \% \\
1111 \%\end{array}$ & $\begin{array}{c}\text { Lymplo. } \\
" 1 / 1\end{array}$ & $\begin{array}{c}\text { Mono. } \\
11 / 4\end{array}$ & $\begin{array}{c}\text { Hetero. } \\
1 / 41\end{array}$ & $\begin{array}{c}\text { Eosin. } \\
\text { "1/" }\end{array}$ \\
\hline & lufested & $\begin{array}{l}14.87 \\
=0.39\end{array}$ & $\begin{aligned} & 78.9 \\
= & 0.5\end{aligned}$ & $\begin{array}{c}0.3 \\
=0.0 .3\end{array}$ & $\begin{array}{l}10.8 \\
=01.4\end{array}$ & $\begin{array}{c}1 \\
=0.11 .1\end{array}$ \\
\hline & Control & $\begin{array}{r}15,0.37 \\
=0 ., 37\end{array}$ & $\begin{aligned} & 81.8 \\
= & 11.2\end{aligned}$ & $\begin{aligned} & 0.2 \\
= & 0.011\end{aligned}$ & $\begin{aligned} & 17.4 \\
= & 11.16\end{aligned}$ & $\begin{aligned} & 11.6 \\
- & 11.116\end{aligned}$ \\
\hline \multirow{2}{*}{2} & Infested & $\begin{array}{l}15.79 \\
\pm 0.7\end{array}$ & $\begin{array}{l}57.3^{* *} \\
\pm 0.4 .5\end{array}$ & $\begin{aligned} & 1.6^{\circ} \\
= & 0.04\end{aligned}$ & $\begin{array}{l}34.6 \% * \\
=11.41)\end{array}$ & $\begin{array}{l}0.5 \% \\
: 0.118\end{array}$ \\
\hline & Control & $\begin{array}{r}1+.6 .8 \\
=11.46\end{array}$ & $\begin{array}{l}78.7 \\
\pm(1) .3\end{array}$ & $\begin{array}{c}0.8 \\
\pm 0.05\end{array}$ & $\begin{aligned} & 20 \\
= & 0.2\end{aligned}$ & $\begin{array}{c}0.5 \\
=0.1)^{2}\end{array}$ \\
\hline \multirow{2}{*}{3} & liffested & $\begin{array}{l}18.87^{* *} \\
\pm 1.117\end{array}$ & $\begin{array}{l}52.4 * * \\
\pm 1.7\end{array}$ & $\begin{array}{l}1.8 \% \\
\pm 0.64\end{array}$ & $\begin{array}{c}37.0^{\circ *} \\
\pm 0.7\end{array}$ & $\begin{array}{l}8.28: 8 \\
=0.2\end{array}$ \\
\hline & Control & $\begin{array}{l}14.8 .3 \\
=0.48\end{array}$ & $\begin{array}{l}70.9 \\
\pm 0.14\end{array}$ & $\begin{array}{c}0.3 \\
\pm 0.05\end{array}$ & $\begin{array}{c}19.4 \\
-0.13\end{array}$ & $\begin{array}{c}0.4 \\
\therefore 0.0 .3\end{array}$ \\
\hline \multirow{2}{*}{4} & Infested & $\begin{array}{c}20.74^{* *} \\
\pm 1.5\end{array}$ & $\begin{array}{l}41.7^{* *} \\
\pm 11.6\end{array}$ & $\begin{array}{l}2.7^{* *} \\
\pm 0.14\end{array}$ & $\begin{array}{l}42 * * \\
\pm 0.5\end{array}$ & $\begin{array}{l}10.0 \% * \\
20 . ?\end{array}$ \\
\hline & Control & $\begin{array}{l}15.11 \\
\pm 0.56\end{array}$ & $\begin{array}{l}801.6 \\
=11.2\end{array}$ & $\begin{array}{c}0.6 \\
\pm 11.0 .3\end{array}$ & $\begin{aligned} & 18.8 \\
= & 0.2 .3\end{aligned}$ & $\begin{array}{l}0 \\
=0\end{array}$ \\
\hline
\end{tabular}

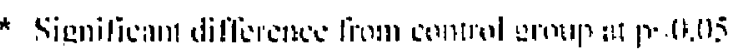


Table (5): Serum cortisol levels in C. idella experimentally infested with Lernare a cyprinacea and control lish.

\begin{tabular}{|c|c|c|c|c|c|c|}
\hline \multirow{2}{*}{$\begin{array}{l}\text { Fish gr. } \\
\text { Time } \\
\text { weclis }\end{array}$} & \multicolumn{3}{|c|}{ Experimentally infested fish } & \multicolumn{3}{|c|}{ Control fish } \\
\hline & $\begin{array}{c}\text { Fish } \\
\text { number }\end{array}$ & $\begin{array}{l}\text { Infest. } \\
\text { Intensity }\end{array}$ & $\begin{array}{l}\text { Cortisol } \\
\text { Level } \\
\mu \mathrm{d} \text {. }\end{array}$ & $\begin{array}{c}\text { Fish } \\
\text { number }\end{array}$ & $\begin{array}{l}\text { Infest. } \\
\text { Intensity }\end{array}$ & $\begin{array}{l}\text { Cortisol } \\
\text { level } \\
\mu \mathrm{d} / \mathrm{dl}\end{array}$ \\
\hline \multirow{6}{*}{1} & $!$ & 0 & 5.2 & 1 & () & 4.9 \\
\hline & 2 & () & 6.6 & 2 & 0 & 5.5 \\
\hline & 3 & () & 7.9 & 3 & () & 0.1 \\
\hline & 4 & 0 & 8.1 & $t$ & () & 0.8 \\
\hline & 5 & (1) & 9.3 & 5 & (1) & 7 \\
\hline & Mean & 0 & $\begin{array}{l}7.4^{\text {it }} \\
\pm 0.7\end{array}$ & Mean & 0 & $\begin{array}{c}6.1 \\
\pm 0.39\end{array}$ \\
\hline \multirow{6}{*}{2} & 1 & 2 & 9.1 & 1 & () & 5.4 \\
\hline & 2 & 3 & 9.7 & 2 & 0 & 6 \\
\hline & 3 & 4 & 11.4 & 3 & 0 & 0.2 \\
\hline & $t$ & 6 & 14.2 & 4 & () & 7.2 \\
\hline & 5 & 7 & 17.9 & 5 & () & 7.3 \\
\hline & Mean & 4.4 & $\begin{array}{c}12.5 \% \\
\pm 1.6\end{array}$ & Mean & 0 & $\begin{array}{r}6.4 \\
\pm 0.37\end{array}$ \\
\hline \multirow{6}{*}{3} & 1 & 5 & $1+.5$ & 1 & () & 5.5 \\
\hline & 2 & $s$ & 18.9 & 2 & () & 5.9) \\
\hline & 3 & 13 & 22.3 & 3 & (1) & 6.4 \\
\hline & 1 & 10 & 23.5 & 4 & (1) & 6.5 \\
\hline & 5 & 1.8 & 311.7 & 5 & (1) & 7.2 \\
\hline & Mean & 12 & $\begin{array}{l}22: 3 \\
\pm 2.7 \\
\end{array}$ & Ne:an & 0 & $\begin{array}{r}6.4 \\
\pm 0.31 \\
\end{array}$ \\
\hline \multirow{6}{*}{$f$} & 1 & 7 & 17.7 & 1 & (1) & 4.7 \\
\hline & 2 & 111 & 21.5 & 2 & 0 & 5.9 \\
\hline & 3 & 13 & 24 & 3 & 11 & 6.3 \\
\hline & + & 22 & 25.6 & 4 & () & 7.6 \\
\hline & 5 & 25 & 33.1 & 5 & (1) & 8.1 \\
\hline & Mcan & 15.4 & $\begin{array}{c}24.4^{*}: \\
\pm 2.6\end{array}$ & Me:an & 0 & $\begin{array}{r}6.5 \\
\pm 0.6 \\
\end{array}$ \\
\hline
\end{tabular}

* Significant diflerence fiom control group al pr:0.05

** Ilighly signilicant difference from control group at $p<0.001)$ | 
Figure (1) Number of clinically infested C.idella post experimental infestation with L.cyprinacea

$\square$ Number of examined fish $\square$ Number of infested fish

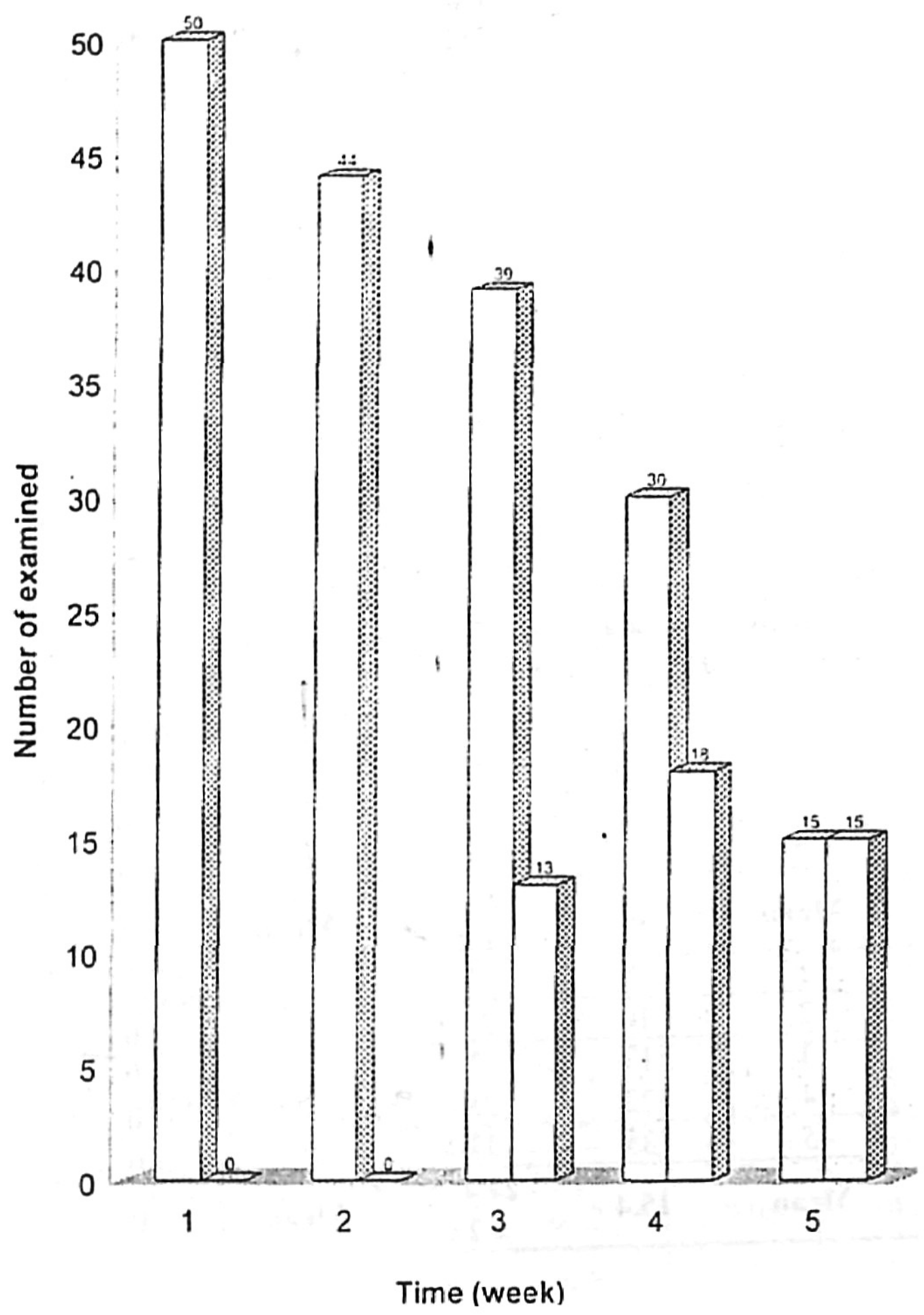


Figure (2) Mean values of RBCs in experimentally infested control C.idella

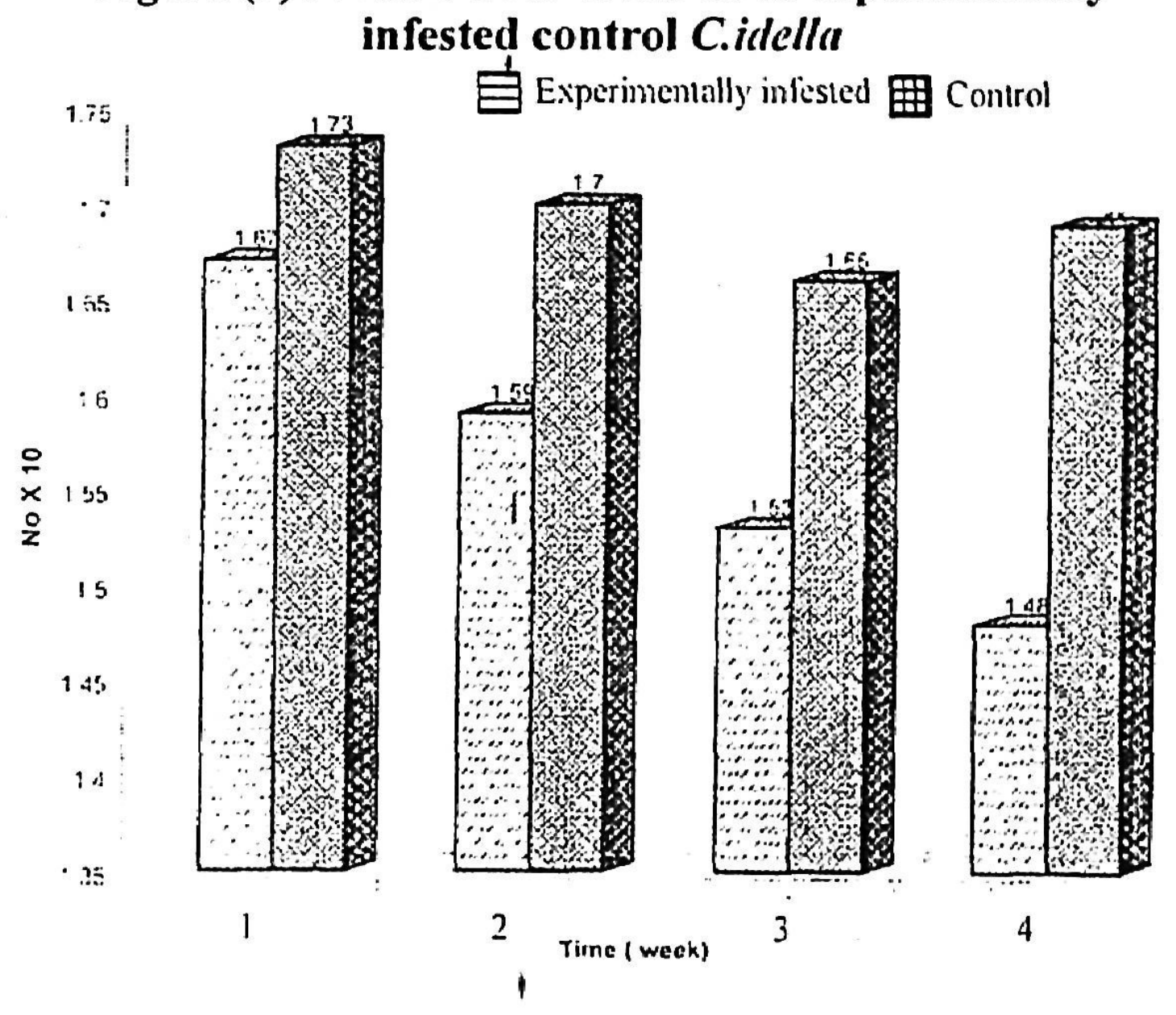

Figure $\{3\}$. Tean values $a f(I b)$ in the experimentally infested and control (:idella

Dinifstes DC̄onuat

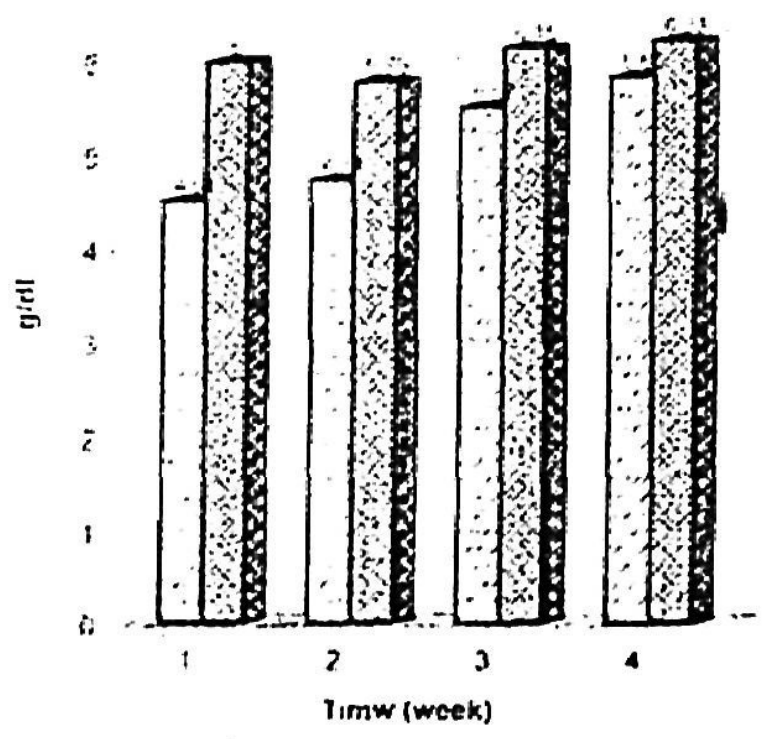

Figure $(t)$ Nean yolues of PC) in the cxperimentally infested and conerol C:idlella

Dinlesters risn aConis:

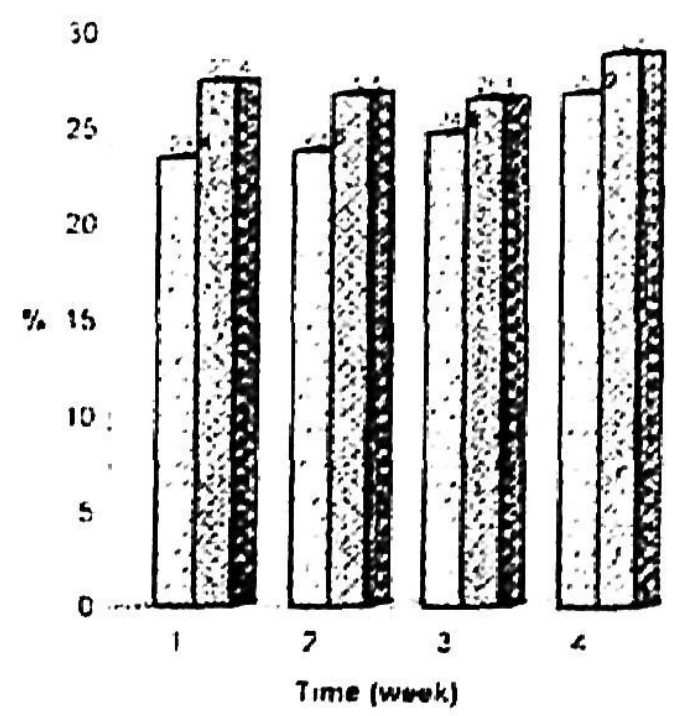




\section{Figure (5) Mean values of WBCs in the experimentally infested C.idellat}

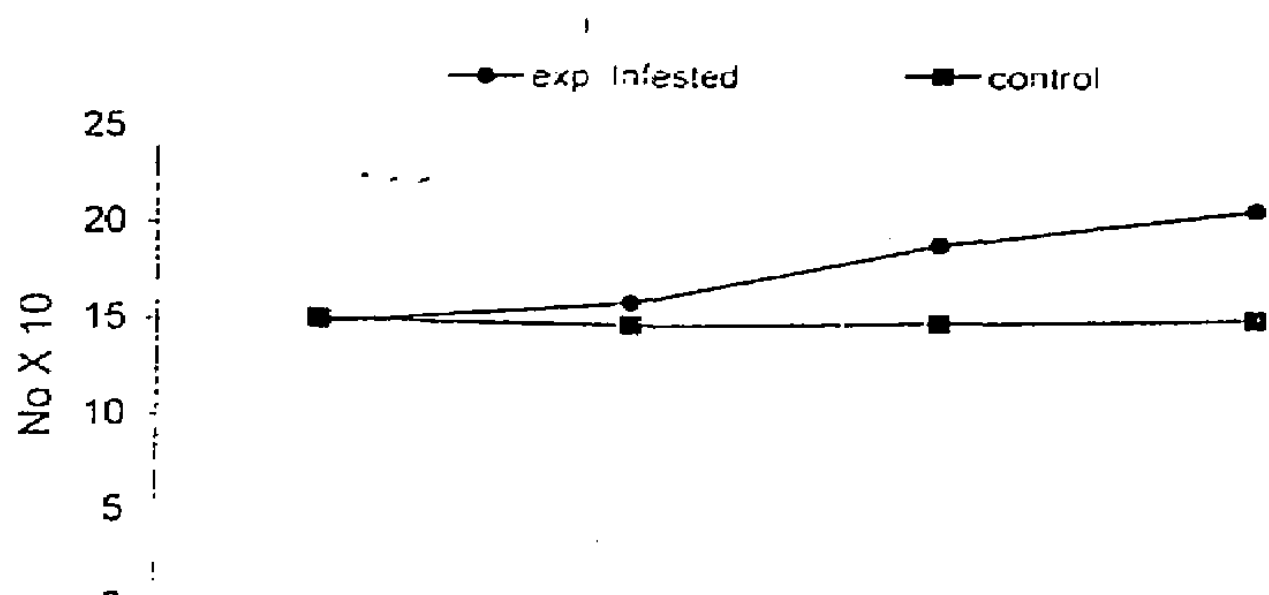

1

Time (weeks)

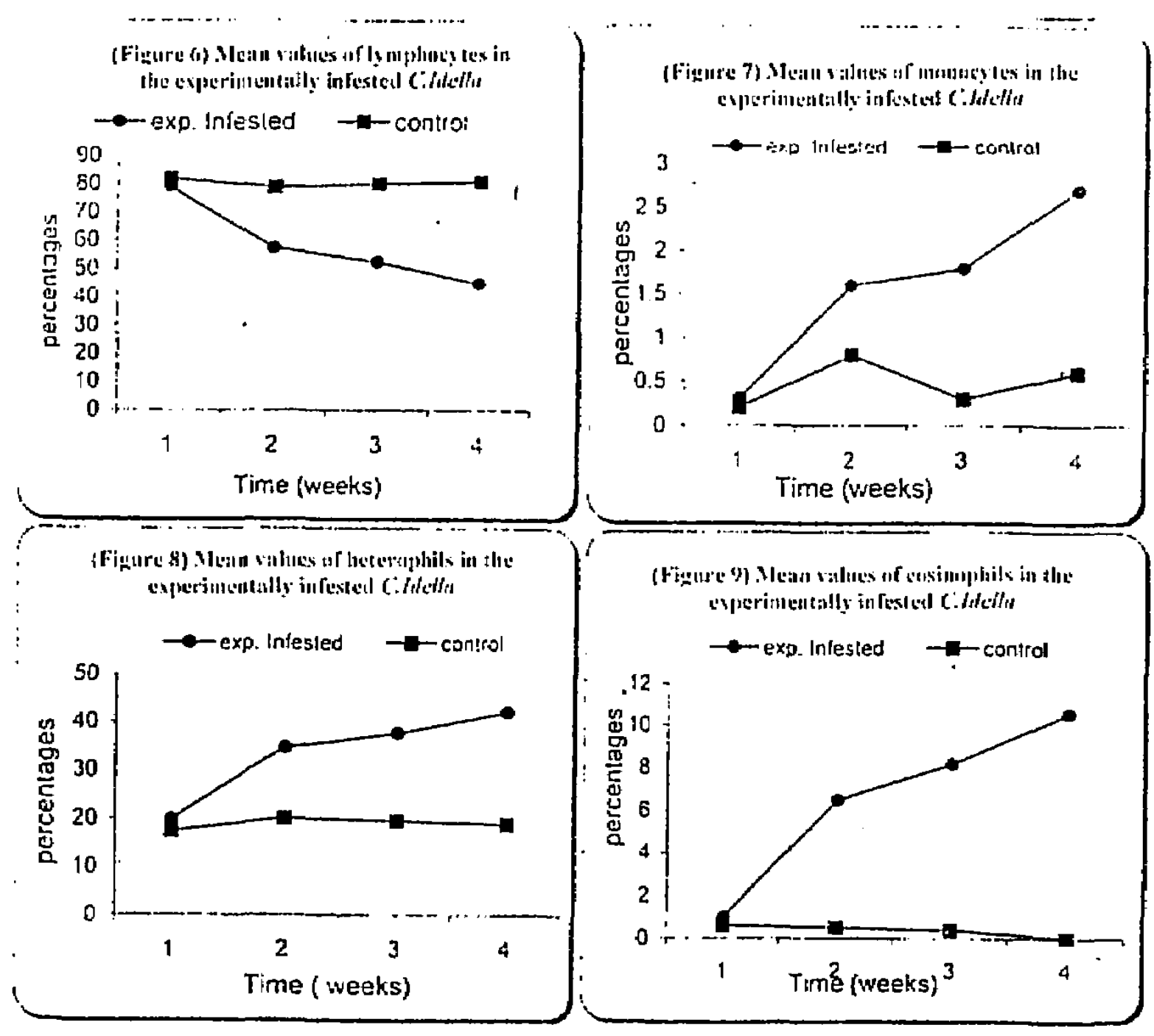




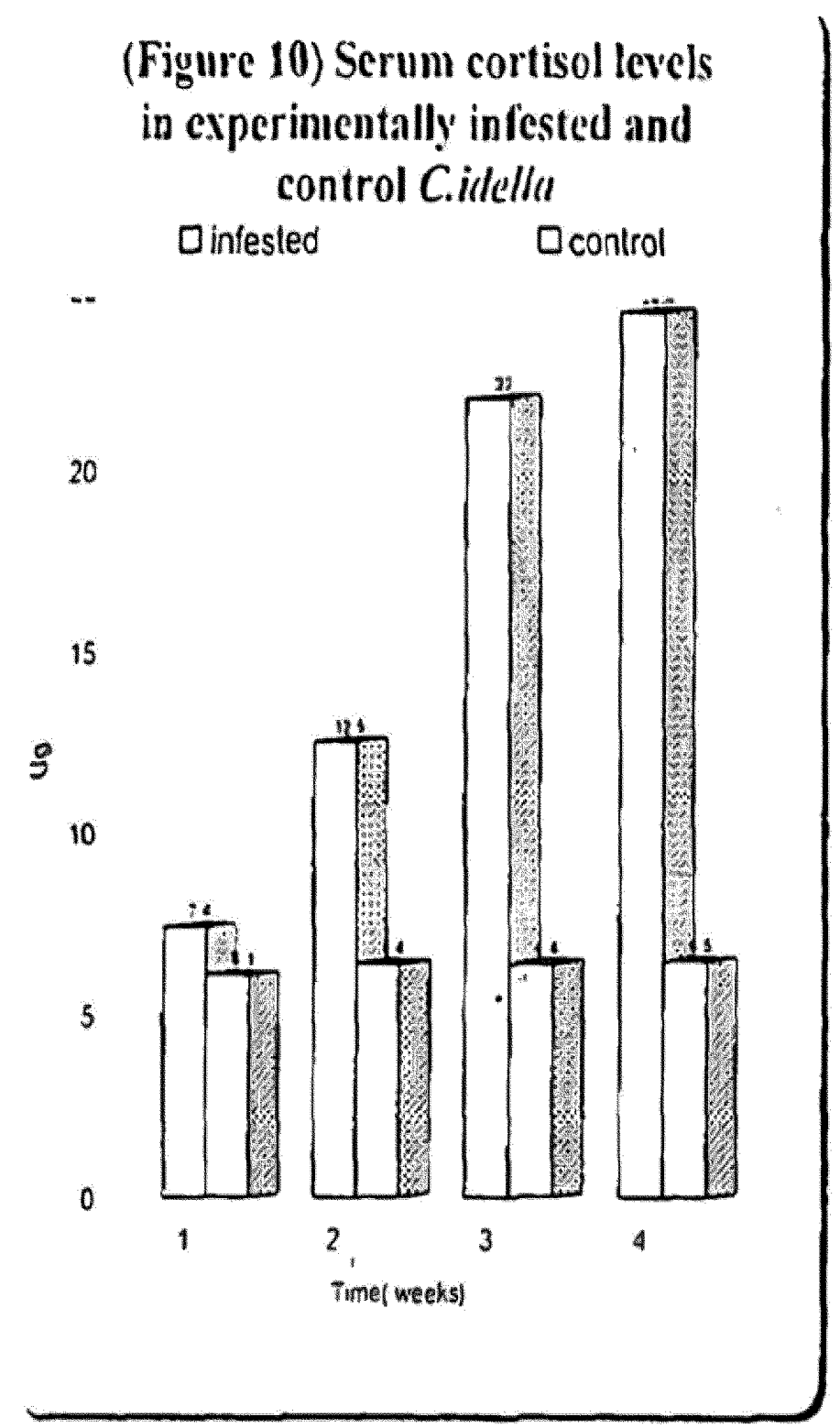




\section{Explanation of photos}

Photo (1): Life cycle of lernata cyprinacea from hatching to the first copepodid (Infective stage).

$(1,2,3)$ stages of egg maturation.

(5) $1^{\text {st }}$ nauplius

(7) $1^{\text {st }}$ meta-nauplius

(9) $1^{\text {st }}$ copepodid

(4) pre-hatched egg

(6) $2^{\text {ind }}$ nauplius

(8) $2^{\text {nd }}$ meta-nauplius

Photo (2): Experimentally infested $C$. idella showing L. cyprinacea and reddening at the base of the dorsal fin on the $14^{\text {th }}$ day after infestation.

Photo (3): Experimentally infested $C$. idella having naris attached $L$. cyprinacea.

Photo (4): Experimentally infested $C$. idella showing L. cyprinacea attached to the gills and inner surface of the operculum.

Photo (5): Experimentally infested $C$. idella showing L. cyprinacea attached to the oral cavity.

Photo (6): Subcutaneous tissue of C. idella, 7 days post experimental infestation showing part of the parasite embedded in the subcutaneous tissue

(H\&E, X40)

Photo (7): Skin of ('. idella. 14 days post experimental infestation showing degeneration and inflammatory cells infiltration in the thick epidermal layer as wel! as granular acidophilic cells infiltration in the dermal layer. (H\&E. X40)

Photo (8): Skeietal muscle of $C$. idella, 14 days post-experimental infestation: Showing diffuse pigmentation between the subcutaneous tissue and necrosed muscle bundles. (H\&E, $\mathrm{X} 40$ )

Photo (9): Skin of C. idella, 21 days post experimental infestation showing edema and inflammatory cell infiltration in subcutaneous tissue and in between the underlying muscle. $(\mathrm{H} \& \mathrm{E} X 40)$

Photo (10): Skeletal muscle and subcutaneous tissue of C. idella. 28 days post experimental infestation showing part of the parasite embedded in the muscle. (H\&E X40) 

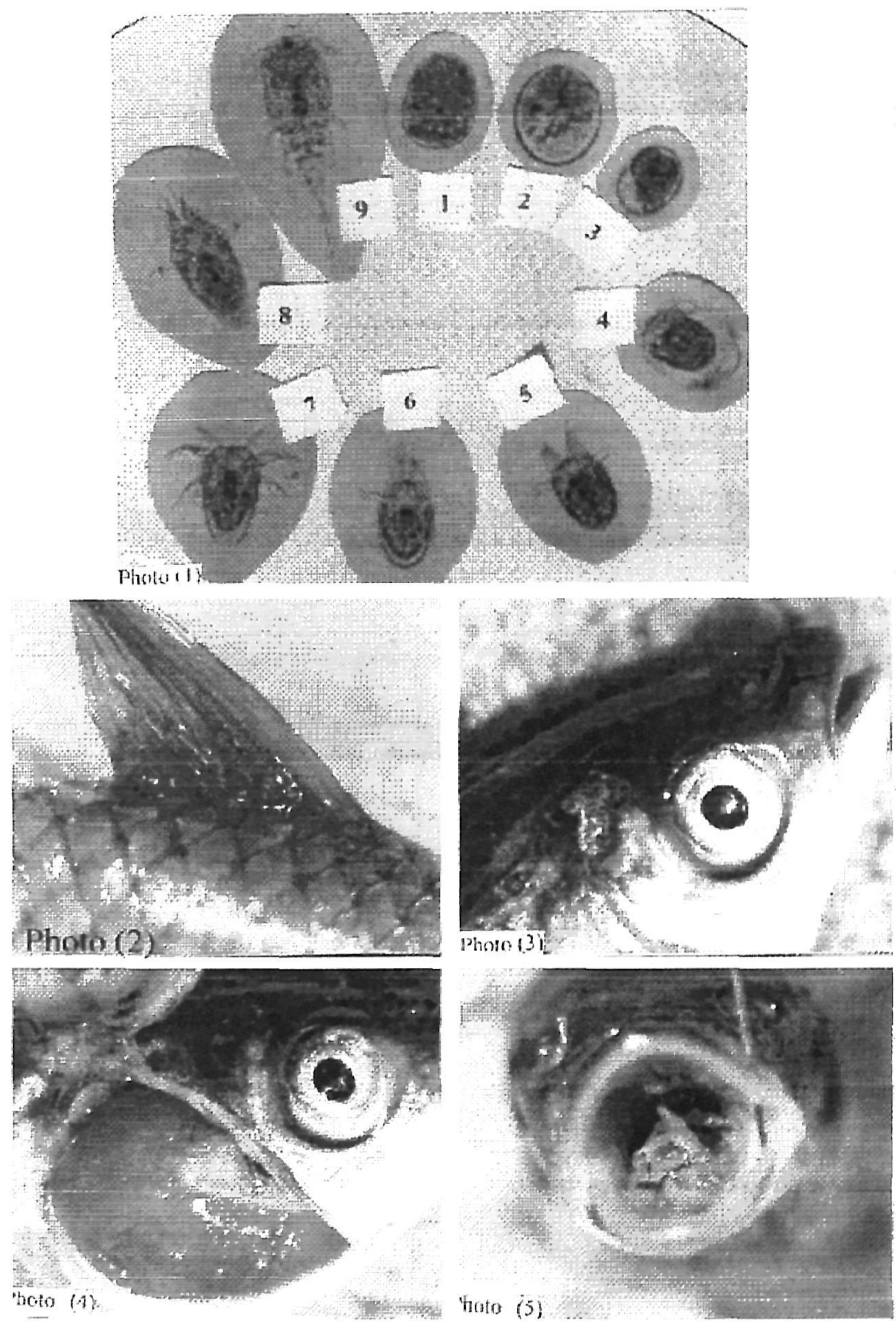


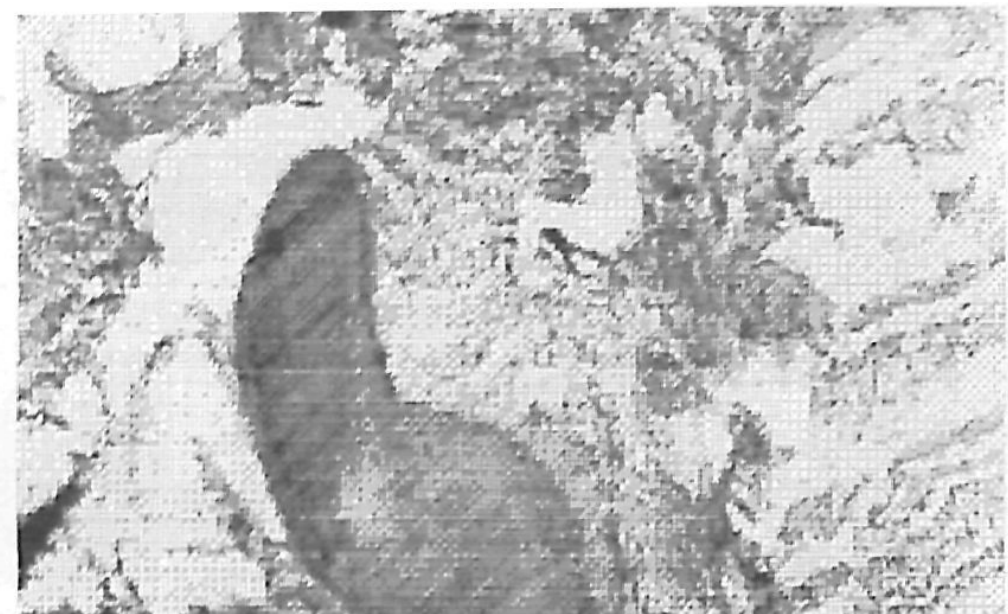

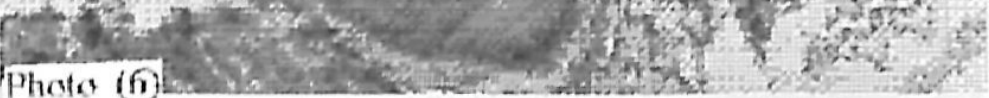
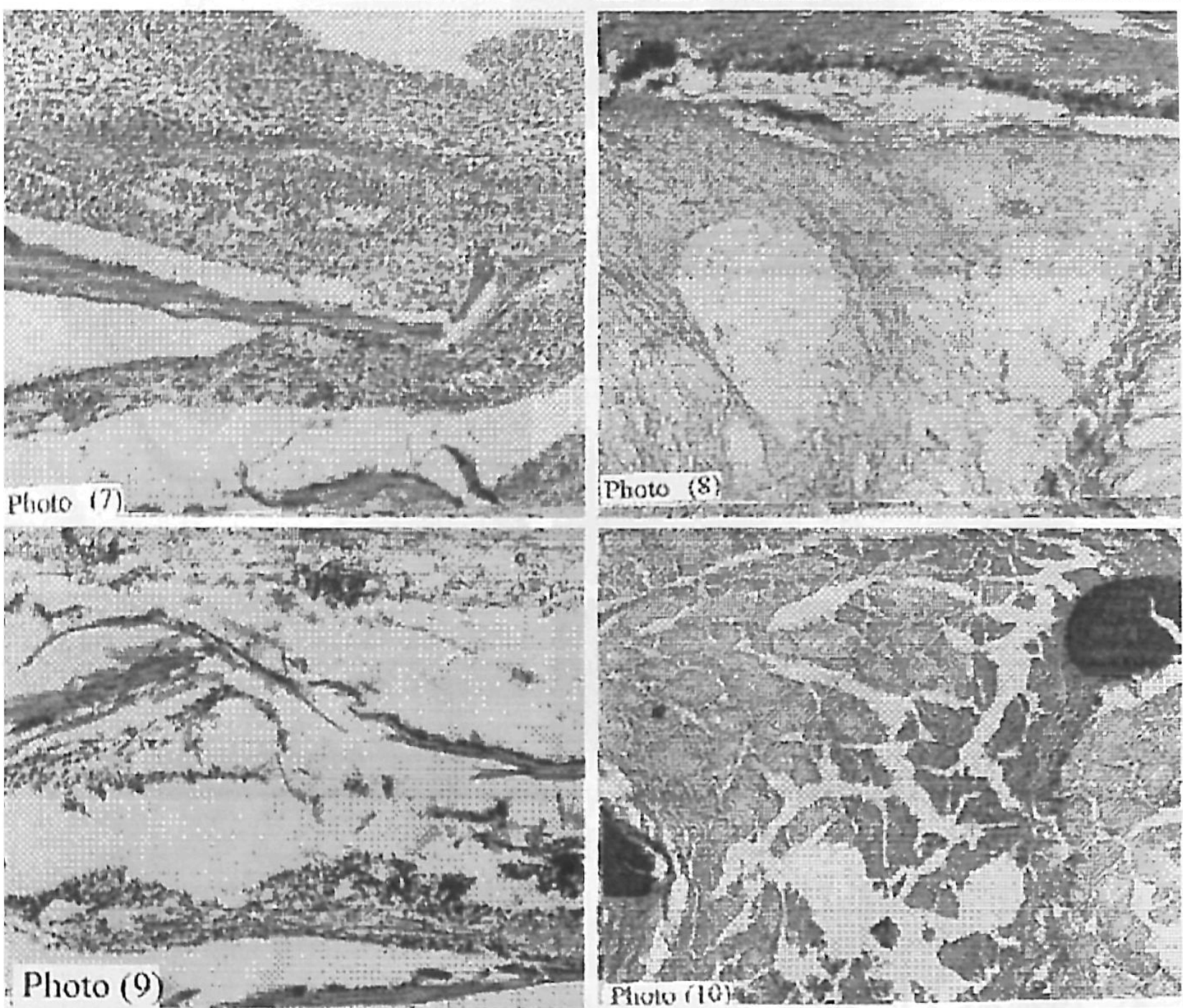

Photo (8)

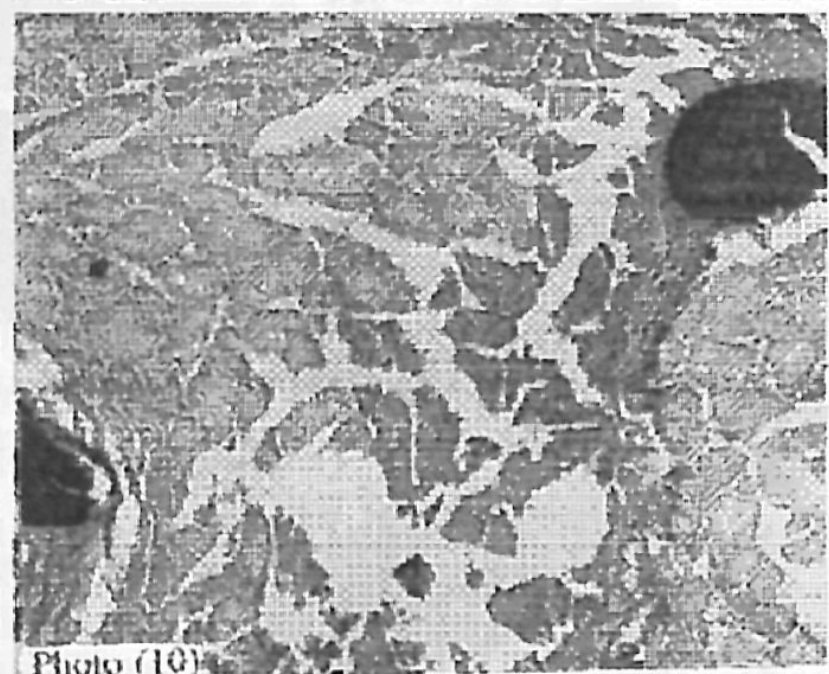

